\title{
No I won't, but yes we will: Driving sustainability-related donations through social identity effects
}

\author{
Guy Champniss \\ Henley Business School \\ guy@enervee.com \\ Hugh N. Wilson \\ Cranfield School of Management, Cranfield University \\ Hugh.Wilson@cranfield.ac.uk \\ Emma K. Macdonald* \\ Cranfield School of Management, Cranfield University \\ and School of Marketing University of South Australia \\ Emma.Macdonald@cranfield.ac.uk \\ Radu Dimitriu \\ Cranfield School of Management, Cranfield University \\ and HBV University College, Norway \\ Radu.Dimitriu@cranfield.ac.uk
}

* $\quad$ Author for correspondence:

Dr Emma K. Macdonald

Cranfield School of Management

Cranfield University

Cranfield

Bedfordshire, MK43-0AL

UNITED KINGDOM

Emma.Macdonald@cranfield.ac.uk

+44 (0) 7788543905 (Mobile)

+44 (0) 1234751122 (work) 


\begin{abstract}
Shifting consumers towards sustainable behaviours is difficult, with an attitude-behaviour gap persistently reported. This study proposes a route towards sustainable behaviours that does not depend on individual attitudes or values: social identity forces within novel online brandconvened consumer groups. A field experiment using a fictitious fruit drink brand demonstrates that by assembling an online consumer group and providing it with sustainability objectives, consumers will engage in a sustainability-aligned behaviour, namely donating to social or environmental charities at the request of the firm, irrespective of their individual attitudes. Furthermore, this behaviour is accompanied by an improvement in brand attachment. As these effects are found within a newly-formed online group, practitioners may be able to achieve sustainability objectives through this mechanism even in the absence of well-established brand communities. The study contributes to social identity literature by demonstrating the impact of group identity effects in a consumer context, and by showing a mechanism by which the negative side of group identity - out-group derogation - can be avoided.
\end{abstract}

Keywords: social identity theory; social categorisation theory; sustainability; consumer behaviour; brand attachment; social media 


\section{Introduction}

Broad social change is needed in the transition towards more sustainable economies (Northrop, 2014; Oliver-Solà, 2010). Towards this, many businesses are widening their sustainability initiatives from a focus on the supply chain to recognising the role played by their customers' behaviour, from product choice (Doran, 2008) and usage (Auger, Devinney, Louviere, \& Burke, 2008) to disposal (White \& Simpson, 2013). Furthermore, many firms are extending their interest in consumer behaviour beyond the firm's immediate product life-cycles, encouraging sustainable behaviours such as donating (Bloom, Hussein, \& Szykman, 1997) and volunteering time to associated good causes (Aquino, Freeman, Reed, Felps, \& Lim, 2009; Reed, Aquino, \& Levy, 2007).

However, businesses focusing their sustainability efforts on changing customer behaviour do so with risk (Osterhus, 1997). While supply-side endeavours are predominantly under the control of the business, customer behaviours are subject to the apparent inconsistencies of those who consume the products and services, who frequently report positive attitudes toward sustainability yet appear not to act on them (Auger \& Devinney, 2007; Hirsh \& Dolderman, 2007; Kilbourne \& Pickett, 2008; Papaoikonomou, Ryan, \& Ginieis, 2011). This can result not just in the firm missing its own sustainability targets but also in costly product launch failures and subsequent reputational damage (Luchs, Naylor, Irwin, \& Raghunathan, 2010).

These risks are well established in the food and drink sector, in which customer behaviour can contribute both positively and negatively to environmental and social objectives (Grunert, 2011; Rutsaert et al., 2015), and changes in this behaviour have proven hard to engender (Verain et al., 2012). As in other sectors, there is a need to establish mechanisms for behaviour change that are more effective than the typical rational communication appeal aimed at changing behaviour via attitude (Stern, Dietz, Abel, Guagnano, \& Kalof, 1999).

This paper proposes just such a mechanism: the use of social influence within technology-enabled consumer social environments. Specifically, we apply social identity theory 
(Tajfel \& Turner, 1986) and the related self-categorisation theory (Hogg \& Turner, 1985; Turner, $1985)$ in the context of online discussion boards. Social identity theory explains inter- and intragroup behaviours (Tajfel, Flament, Billig, \& Bundy, 1971), while self-categorisation theory explains how and why individuals make the psychological commitment to such groups (Turner, Wetherell, \& Hogg, 1989). We propose and test that social identity can form a mechanism for driving sustainability behaviours without the need to invoke pro-sustainability attitudes. We further propose and test that this mechanism can also improve the consumer-brand relationship, an important outcome as it is possible for sustainability programmes to damage rather than enhance this relationship (Aaker, Vohs, \& Mogilner, 2010; Luchs et al., 2010). This is particularly relevant for the food and drink sector, a competitive environment in which the brand relationship plays a crucial part in consumer choice (Macdonald \& Sharp, 2000).

Some previous work has investigated alternatives to the typical rational communications appeal: product choice, for example, may be influenced by choice editing (Pepper, Jackson, \& Uzzell, 2009) and by price differentials (Auger, 2003). In this study, however, we focus on a sustainability behaviour that is hard to influence with such techniques, namely securing financial donations from the firm's consumers to third parties such as social or environmental charities - a behaviour which may make an important contribution to achieving sustainable economies.

We conduct an empirical test of these ideas through a novel field experiment, using a representative sample of active consumers within the drinks category. Conceptually, we contribute to the sustainable consumer behaviour literature by showing an approach to behaviour change through social forces. We also contribute to social identity literature by applying group effects within a consumer context. A further contribution is to the social influence literature, testing influence effects within novel group structures. From a practitioner perspective, this study provides marketers with a new way to engender specific sustainable consumer behaviours without the need to target only the subset of consumers with pre-existing pro-sustainability attitudes. 


\section{Theoretical Development}

\subsection{The potential of social identity theory for engendering sustainable behaviour}

Social identity theory (SIT; Tajfel, 1970) seeks to explain why we act the way we do via group membership. More specifically, SIT proposes that our behaviour is influenced as a result of psychological commitment to groups, where specific social groups (whether formal or informal) are indicative of specific social identities (Tajfel \& Turner, 1986). Social identities are shared by collections of individuals who are similar on salient dimensions (Tajfel, 1978). These social identities can vary in degree of abstraction (Brewer \& Gardner, 1996), from the more abstract (e.g. responsible citizen) to the more specific (e.g. local football team supporter). Social identities, which are constantly changing depending on the social context, combine with our more stable personal identity to form our self-concept (Turner \& Oakes, 1997), which shapes our behaviours at any given time. Importantly, the sister theory of SIT, self-categorisation theory (SCT; Turner, 1985), proposes that group membership occurs when psychologically committing to that group - that is, self-categorising with the group - will remove social ambiguity. The chosen group presents the individual with a clearer view of how to act within the social environment at that moment, as well as how to act in accordance with the group identity, thus further improving both the 'positive distinctiveness' of the group (Tajfel, 1978) and the individual's position within it. Once one accepts one's membership of the social group, one strives to become the perfect - prototypical - member of that group (Tajfel et al., 1971) by enacting behaviours congruent with the social identity and supportive of the group.

We suggest that these social forces as depicted by SIT and SCT are important for sustainable consumer behaviour for several reasons. First, if our behaviours are a product of our self-concept, which in turn is a product of both personal and social identities, then our behaviours will be highly dependent on the groups we feel we belong to at any moment (Reed, 2002). However, we may come into contact with several groups simultaneously, and with a different set of groups shortly afterwards, so the relationship between attitudes and behaviours is 
not stable. This view potentially offers at least a partial explanation for the persistent attitudebehaviour gap discussed earlier. This leads to the second important aspect of a SIT view of consumer behaviour: if self-categorisation with the group is driven by a desire to remove social ambiguity, then individuals will constantly trade off different social groups against each other as they look for the clearest opportunities for positive distinctiveness in their current social context (Hogg \& Abrams, 1990). Hence behaviours may vary with social context rather than necessarily aligning with personal attitudes. Moreover, in some contexts behaviours that are considered supportive of an individual's personal identity may be abandoned due to the risk of betraying the salient social identity (Turner et al., 1989) and thereby marginalising or excluding the group member.

Social influences appear to be at work within many of the technology-enabled consumer environments today, for instance in the peer review processes of such sites as TripAdvisor and Amazon. Whilst behaviours such as reviewing are not overtly sustainable, we observe that they are at least prosocial, in the sense that they involve the outcome of helping others within an implicit peer group to choose. Consistent with this argument, within the brand community literature (Schau, Muñiz, \& Arnould, 2009; Schouten, 2007) in-community behaviour can be seen as motivated by social identity (Dholakia, Bagozzi, \& Pearo, 2004). Indeed, one of the root qualities of community membership is defined as a 'consciousness of kind' (McAlexander, Schouten, \& Koenig, 2002), which, we suggest, reflects the sense of belonging to the group at a psychological level as a result of self-categorisation. A second root quality of brand community membership is a 'moral responsibility' (McAlexander et al., 2002) toward other community members. Again, this can be seen from a SIT perspective as a result of self-categorisation, with group members striving to support each other, as a means to increase the likelihood of the group strengthening its positive distinctiveness.

However, to assign such behavioural influences solely to well-established and wellresourced brand communities risks overlooking one of the most interesting aspects of SIT that 
has not, to our knowledge, been applied to the consumer context. SIT research reports that such behavioural effects are not reliant on the mature group structures of a long-standing social group, but can be recorded even with the simplest and most modest group structure (Tajfel et al., 1971) and however recently the group has been formed (Levine, Evans, Prosser, \& Reicher, 2005). Even when participants are allocated arbitrarily to specific groups, in-group favouritism quickly appears (Tajfel, 1970). We propose that this characteristic of group behaviour is important for sustainable behaviour for two reasons. First, the fact that these effects are observed with even the most rudimentary social groups suggests that new groups can perhaps be created with relative ease and with modest budgets. Second, as the resulting group's behaviours are congruent with the identity associated with the group, the ability to create novel groups presents the opportunity to build groups around a specific behavioural outcome that is sought. We now develop these ideas with respect to an example of such a desired behaviour, namely financial donations to good causes.

\subsection{Donating as an identity-supporting behaviour}

As we have discussed, there are many consumer behaviours that have sustainability implications, from product choice to product disposal. For our empirical work we choose one such behaviour, financial donations at the instigation of the brand, for four reasons. First, the pledging of money is a clear example of a behaviour that delivers benefits to others (Reed et al., 2007; Shang \& Croson, 2006; Strahilevitz \& Myers, 1998; Twenge, Baumeister, DeWall, Ciarocco, \& Bartels, 2007) and thus it illustrates how sustainability objectives which go beyond a consumer's immediate instrumental and hedonic benefit can be met. Second, many initiatives that are attempting to bring about social change in order to address chronic sustainability issues whether from a societal or environmental perspective - are dependent on such donations (Lichtenstein, Drumwright, \& Braig, 2004; Small, Loewenstein, \& Slovic, 2007; Winterich \& Barone, 2011). Third, despite its importance, the extant research shows that requesting financial donations from consumers can be complicated by the negative psychological effects of money 
on such giving behaviour (Guéguen \& Jacob, 2013; Vohs, Mead, \& Goode, 2006). Again, money is involved in some other important sustainable behaviours, such as where the price of a sustainable product differs from alternatives, so a donation behaviour again provides an example which may have wider applicability. Fourth, the behaviour is additionally difficult to engender since it cannot be directly sought through an explicit value exchange (Bagozzi, 1975) between the consumer and the business (as is the case with a direct product purchase), challenging businesses to encourage such behaviours without a typical reliance on product-related features.

We further choose to focus on a specific form of financial donation, namely 'precommitting' to a financial donation (Meyvis, Bennett, \& Oppenheimer, 2010), since it has been shown that securing such a precommitment to donate is effective in encouraging actual subsequent donations (Kivetz \& Simonson, 2002; Meyvis et al., 2010). This is due to decoupling the positive effect of giving from the 'pain' of spending (Meyvis et al., 2010; p46). Securing the commitment ahead of the donation ameliorates the sense of financial loss (Ariely \& Wertenbroch, 2002; Loewenstein \& Prelec, 1992), controlling for the endowment effect (Kahneman, Knetsch, \& Thaler, 1991) whereby possessions (including money) are imbued with additional subjective value, which may counter the desired social identity effect. Hence, precommitment to donate forms a dependent variable that is strongly associated with donation behaviour and indeed is a sensible initial objective for practitioners. It also has the benefit for our study of being practical with limited research budgets. We further choose to present this precommitment request via participants being entered into a prize draw to win a further fee for undertaking the research. We then ask for a precommitment to share a proportion of this additional fee with a good cause were the participant to win. The use of a lottery mechanism to secure a precommitment has been shown to be effective (Meyvis et al., 2010).

In the light of our previous conceptual discussion, we consider the case of an individual who is currently within an online brand-convened group setting along with other individuals. If a behaviour such as donating improves the positive distinctiveness of the group, then the 
individual is more likely to enact the behaviour (Tajfel, 1982), as individuals work to improve the status of groups to which they belong, however temporarily (Tajfel et al., 1971). Notably, if the group identity involves sustainability as a group objective, then donating to a cause which is seen as sustainability related will increase, as compared with a group whose identity is not sustainability related. For precision, we define behaviour-identity congruence as the extent to which a behaviour both supports and adds to the group's positive distinctiveness. So greater behaviour-identity congruence will be associated with increased displays of the behaviour, as group members strive to deliver the behaviour in order to improve the group's positive distinctiveness and status (Tajfel, 1982; Tajfel, 1978). This effect is expected even in novel groups, as the minimal group paradigm (Tajfel et al., 1971) demonstrates that individuals work to improve positive distinctiveness as soon as a group is created. Notably, the resulting behaviours do not depend on the individual's prior attitudes or values (Hogg \& Turner, 1985; Tajfel et al., 1971; Tajfel, 1978). This leads to the first of our two hypotheses:

H1: When a brand makes a behaviour request in a brand-convened group, higher behaviouridentity congruence will result in increased levels of the behaviour.

\subsection{Identity-supporting behaviours and the consumer-brand relationship}

Sustainability initiatives need to be viable for the business which requests this behaviour. We have observed that negative reputational outcomes are possible for consumer-facing businesses driving sustainability initiatives (Luchs et al., 2010). Compromised brand equity can result in loss of customers, loss of sales from remaining customers, and increased price sensitivity (Aaker et al., 2010). We therefore test the effect of sustainability behaviour requests in an online group setting on the consumer-brand relationship, as indicated by the consumer's level of brand attachment (Park, Macinnis, Priester, \& Eisingerich, 2010; Park, MacInnis, \& Priester, 2006), a more valid predictor of purchase behaviour than brand preference (Park et al., 2010). 
One reason for the vulnerability of the consumer-brand relationship in sustainability endeavours is that such efforts typically focus on association shifts toward the target sustainable outcomes (Stern et al., 1999). These modified associations may then clash with those associations held toward the brand in question (Luchs et al., 2010). For example, more feminine associations typically held toward sustainability efforts may clash with masculine brand associations relating for instance to brands strongly positioned on performance (Aaker et al., 2010). However, we would not expect such negative effects to be present using the social identity mechanisms we propose, since this social identity influence occurs at a behavioural level, not an attitudinal level, as group members strive to support and improve their group with identity-congruent behaviours (Hogg \& Abrams, 1990; Hogg \& Turner, 1987).

Indeed, on the contrary, a sustainability-related behaviour request through a social identity mechanism may have a positive, not a negative, effect on the brand relationship. Where the request is identity congruent due to a group identity that strongly includes sustainability, we have seen that increased sustainability behaviours are expected, resulting in stronger positive distinctiveness for the group and higher perceived homogeneity within it (Turner \& Oakes, 1986). This leads to an individual continuing to select the group as salient, as group homogeneity reduces ambiguity as to how to behave (Turner, 1985). In our case of a brand-convened online group, the group contains the focal brand, since the brand - via its representatives (marketers) convenes the group and provides its distinctive identity. As a result, as consumers continue to self-categorise with the group (Turner, 1985), in-group favouritism (Tajfel et al., 1971) will include attachment to the brand, as a member of the in-group. Hence, the greater the behaviouridentity congruence, the greater the brand attachment. This gives rise to our second hypothesis:

\section{H2: When a brand makes a behaviour request within a novel brand-convened group, higher} behaviour-identity congruence will result in higher brand attachment. 
To summarise this section, we propose that social identity effects, generated by creating a novel social group on behalf of a focal brand and manipulating its identity, can lead to increases in sustainability behaviours - in the case of our experiment, committing to financial donations to related charities which are campaigning on sustainability issues. Furthermore, we propose that brand attachment will strengthen rather than weaken as a result of the request to donate when this request is made through such a social identity mechanism.

\section{Method}

To test this argument that novel group structures can both lead to sustainable consumer behaviour outcomes and bolster the consumer-brand relationship in the process, we developed an online field experiment in which consumers were asked to help the owner of a (fictional) brand to refine a series of potential marketing initiatives prior to product launch. Participants did so via an online platform that was accessed from their own laptops or PCs, as is typical for such marketing concept testing procedures, in the interests of ecological validity.

\subsection{Cover Story}

The product in question was a fruit 'smoothie' drink. The brand was described as being both contemporary (in terms of using innovative production techniques and being available in a range of channels for the consumer) on the one hand, and healthy and potentially sustainable (due to its high fruit content and its manufacturing process) on the other. Participants were informed that 'one small bottle contains two of your five-a-day, making it as easy as possible to get as much fruit as you want, in the healthiest way possible and without getting in the way of your busy life.' These brand attributes of being contemporary and being healthy/sustainable were useful for the manipulation of behaviour-identity congruence, as we discuss shortly.

As part of the planned brand launch, all participants were shown two potential marketing communications initiatives. One focused on nature and the second on society, so between them they covered the two main areas of sustainability, social and environmental sustainability. Two 
initiatives were used in order to control for any potential participant preference for one of these areas over the other. To do this, all participants were asked to comment on both of the draft initiatives, but the order in which they were presented was reversed for a random half of the sample, to remove any primacy or recency influences (Miller \& Campbell, 1959) on initiative recall ahead of the measurement of dependent variables.

Between seeing the first and second initiatives, participants were made aware of a number of charities, combined as an entity entitled 'The Charity Consortium', that were supposedly interested in taking part in a similar initiative to support their charitable efforts. These included for example Worldwide Fund for Nature (WWF) and the UK's National Trust, and the set of charities was chosen so it could plausibly be associated with either initiative. Because the initiative order was randomised, the charities were also associated with both the environmental and the societal initiative within the sample.

\subsection{Behaviour-identity congruence manipulation}

Behaviour-identity congruence was manipulated via two conditions: high behaviouridentity congruence (HC) and low behaviour-identity congruence (LC). See Table 1 for details. In the LC condition, participants were told that the brand was about to launch, and that due to the competitive nature of product launches in categories such as this, the brand team wanted to gather as much feedback as possible about the draft launch initiatives. In this condition, the participants were given a typical marketing objective for undertaking market research, namely supporting as successful a product launch as possible through satisfying customer needs. In this way, the more typical brand attribute as a contemporary, customer-focused brand was accentuated. In the second, $\mathrm{HC}$ condition, participants were informed that their role was to help launch the brand as a sustainable choice for consumers, and as a brand that supports sustainable choices elsewhere (across both environmental and societal issues). For this condition, the sustainability brand attribute was accentuated, increasing congruence of the group's identity with the donating behaviour requested later. 


\subsection{Measures}

The precommitment to donate was measured by offering participants the option to split a possible additional payment they may receive with the array of charitable third parties also allegedly involved in the initiatives. More specifically, participants were told they were being entered into a lottery to win an additional payment of $£ 10$ on top of their regular fee of $£ 10$ for participating in the market research exercise, and that they could commit now to share a proportion of any additional payment they might win with the charities involved. Participants were asked to select how much they wished to donate in this manner, from 11 options in multiples of $£ 1$ ranging from $£ 0$ to $£ 10$. We chose $£ 10$ as this mirrored the initial fee; any lower, and we were concerned that the win might not be relevant to them (thus potentially influencing their precommitment), while any higher may result in their questioning the effort required to complete the research, if more could be secured just by chance.

The consumer-brand relationship was measured using an established parsimonious brand attachment scale (Park et al., 2006). As the cover story used an fictional new brand, two items within the scale designed to control for brand prominence and top-of-mind were removed, since the experimental design controlled for this. Consequently, brand attachment was measured using two brand-self connection items measured on an 11-point, Likert scale anchored by 'Not at all' and 'Completely': 'In helping us today and carrying out this exercise, to what extent do you feel Abundancy [the brand name] is a part of you, and who you are?', and 'In carrying out this research today, to what extent do you feel that you are personally connected to Abundancy?'.

\subsection{Pre-tests}

The fictional brand and associated marketing materials were reviewed by both academic and practitioner marketing colleagues prior to their use, to test for ecological validity. The full 
experimental instrument was then run with six colleagues to check for overall face validity. Following these validity pre-tests, the experimental instrument was tested using pen and paper surveys with two student samples, to further test face validity and to ensure the behaviouridentity congruence manipulation was operating correctly. When asked, all the students correctly stated whether the goal of the brand launch was commercial or sustainability related.

\subsection{Sample}

A sample of 121 consumers who were active in the product category was recruited from an established market research panel provider which commonly asks its members to review marketing launch initiatives as described in the cover story.

\subsection{Procedure}

Participants were welcomed and received instructions regarding the task for the session, namely the review of marketing materials for the launch of a new fruit-based smoothie. Participants were induced to assume that the brand was a genuine one, to increase ecological validity. For all participants, the product was introduced with its benefits identified as both contemporary and healthy/sustainable, as described earlier, allowing both conditions to be plausible. All participants were told that they were going to review and provide feedback on two potential launch initiatives for the brand. Participants were then split (at random) into the two behaviour-identity congruence conditions. As described earlier, for the high behaviour-identity congruence condition $(\mathrm{HC} ; \mathrm{n}=61)$, participants were told that both of the initiatives focused on trying to establish the brand with a pro-sustainability positioning. A rationale for this was given, and references were made back to the health-oriented aspect of the product. For the low behaviour-identity congruence condition ( $L C ; n=60$ ), participants were told that both of the initiatives focused on launching the brand successfully within the market through the typical commercial mechanism of good customer experience. See Table 1.

All respondents then saw the same two initiatives, one focused on nature and one on 
society. As mentioned earlier, the order of presentation of the initiatives was rotated for half of the sample. Next, the initiatives are explained in more detail.

\subsection{Proposed marketing communications initiatives}

After introducing the brand, two proposed marketing communications initiatives were presented to participants for comment. See Table 1. One initiative, termed 'Just Add Nature', centred on the natural world and offered consumers the chance to win an extreme nature/adventure holiday. The initiative was described as 'pick up a bottle of Abundancy and you could find yourself picked up and taken on the adventure of a lifetime. For a limited time, Abundancy is offering you the chance to experience the natural world in all its glory, first hand.' For participants in the $\mathrm{HC}$ condition, this holiday was justified as being important from a sustainability perspective, since more contact with the natural world leads to more people protecting the environment. For those in the LC condition, it was justified instead by referencing the growing popularity of contemporary 'extreme' holidays for the excitement and adrenaline rush. The face validity of the initiatives was enhanced with the presentation of three genuine magazine / newspaper articles. In the LC condition, these espoused the benefits of extreme holidays; see Figure 1 for an example. In the HC condition, these discussed the importance of connecting with the natural world for environmental respect; see Figure 2 for an example. The aim was to improve face validity by providing a descriptive normative influence (Cialdini, Reno, \& Kallgren, 1990), describing typical behaviours in support of the initiative. Participants did not have to read the articles: they were presented as pdfs that would open if they wanted to read more about why the brand was committing to these initiatives. However, the titles were visible, so providing face validity for the initiatives was increased just by their presence.

--- Insert Figures 1 and 2 about here ---

Figure 1: Example article on environmental initiative - low behaviour-identity congruence (LC) condition

Figure 2: Example article on environmental initiative - high behaviour-identity congruence $(\mathrm{HC})$ condition 
The other initiative, which had a societal theme, proceeded in a similar manner. Termed 'Sporting Chance', it offered support for a series of inner-city sports programmes. It was introduced with: 'wouldn't it be cool to do sport with the proper kit? In the proper place? And with professional coaching? Abundancy's Sporting Chance initiative - helping more people enjoy more sport.' For the HC condition, the following text stressed that it was important to engage in exercise young people who have poor access to sport, in order to promote healthy lifestyles and community building. For the LC condition, the sports programmes were positioned as being enjoyable for the individual, with benefits such as the adrenaline rush, career networking opportunities, and making the most of a modern, busy lifestyle. As with the environmental initiative, three supporting magazine/newspaper articles were presented in both conditions.

Prior to describing the second initiative, all participants were made aware of a series of charities that had been instrumental in developing the initiative, and that were considering running similar initiatives in partnership with the focal brand. As the initiative order was reversed for half of the sample in each condition, the charities were linked to both the 'Sporting Chance' and 'Just Add Nature' initiatives.

After reviewing the second initiative, all participants were informed that as a gesture of thanks from the smoothie drink brand team they would be entered into a draw to win an additional amount of money, on top of their payment. They were informed that if they won, they could donate a proportion of this additional amount to the charity consortium. They were asked how much, if any, of the prize they would wish to donate, as described earlier, and were informed that if they chose not to donate, this would not influence their chances of winning the draw. Finally, participants were informed that if they won and had chosen to donate, the donation would be administered by the research company and they would receive their payment 
and winning amount net of the donation. Participants were then asked to complete the brand attachment items.

Having completed the study, participants were thanked for taking part in the research and were invited to disconnect from the online platform.

\section{Results}

Although the behaviour-identity congruence manipulation was checked within the pretests, a manipulation check was run to ensure that the high behaviour-identity congruence (HC) condition participants understood that the specific goal of their group was a sustainable brand launch, and similarly that the low behaviour-identity congruence (LC) condition understood the standard commercial launch purpose. This check used a three-item semantic differential scale (for example, 'The goal of my group today was to help the brand launch as a sustainable product' versus 'The goal of my group today was to help the brand launch as a commercially successful product'). A chi-squared test was significant $\left(x^{2}(3)=19.84, \mathrm{p}<.01\right)$, indicating that the group purpose was understood.

The effect of behaviour-identity congruence on donation behaviour was significant ( $\mathrm{F}(1$, $118)=4.85, \mathrm{p}<.05)$, with those in the $\mathrm{HC}$ condition showing higher levels of donation behaviour $\left(\mathrm{M}_{\mathrm{HC}}=6.93\right)$, than those in the LC condition $\left(\mathrm{M}_{\mathrm{LC}}=5.45\right)$. In sum, participants in the HC condition were willing to donate most of their additional payment to the charity consortium, while those in the LC condition wished to retain most of it. Consequently, H1 is supported. The charity connection to each specific initiative did not significantly influence precommitment to donate (environmental initiative, $M=7.1(\mathrm{sd} 3.32)$; societal initiative, $M=6.67,(\mathrm{sd}=2.87) \mathrm{p}>.1)$.

Although we find support for H1, an alternative explanation could be that the sustainability identity caused group members to psychologically commit more strongly to (that is, to self-categorise more strongly with) the group. This might be plausible as the goal and associated identity could seem to be more vivid or distinctive to start with, when compared to the 
commercial goal. In which case, the behaviour could have been a product of stronger selfcategorisation rather than behaviour-identity congruence. If this were indeed the mechanism for H1, we would expect that self-categorisation would mediate between the manipulation and the dependent variable, namely the commitment to donate. We checked for this, using 9 items from the 10-item social categorisation scale developed by Ellemers et al. (1999). (A tenth item, 'I would rather belong to the other group', was removed for face validity reasons, as it is inapplicable in this context.). A mediation test following Hayes's (2013) PROCESS and INDIRECT algorithms, involving a bootstrapping multi-step mediation analysis with 1000 samples, showed that the total indirect effect is not significant as the confidence interval spans zero ([CI] [-.0035 -.1610]). That is to say, there is no significant mediating effect of social identification on the relationship between the behaviour-identity congruence manipulation and donation behaviour. Hence we reject this alternative explanation.

Turning to our second hypothesis regarding the potential impact of the behaviour request on the consumer brand relationship, the effect of behaviour-identity congruence on brand attachment was also significant $(\mathrm{F}(1,118)=6.07, \mathrm{p}<.01)$, with those in the $\mathrm{HC}$ condition showing higher brand attachment $\left(\mathrm{M}_{\mathrm{HC}}=7.48\right)$ than those in the $\mathrm{LC}$ condition $\left(\mathrm{M}_{\mathrm{LC}}=6.35\right) . \mathrm{H} 2$, then, is also supported.

\section{Discussion}

We have proposed that consumers' increasingly online lifestyles can be used to generate social identity effects in brand-curated online environments and that these can lead to brand requested sustainability behaviours, irrespective of the attitudes held by those consumers. We have also argued that such effects can lead to a more positive association with the brand as a result of the behaviours they create. Our results show that a specific sustainable behaviour can indeed be engendered without a focus on attitudinal change, as is typically prescribed within the sustainable consumer behaviour context. Therefore, prior attitudes towards sustainability would appear less crucial in securing sustainability behaviours than is typically assumed, revealing 
opportunities for consumer engagement that extend considerably beyond those more typically considered.

The sustainable behaviour within our study, donation to sustainability charities at the request of the brand, is only one such behaviour needed for broad social change. However, we do propose it is an important behaviour and indeed one that is hard to engender, due in part to there being no tangible exchange between the brand and the consumer, and given the wellidentified negative effects of money in the context of prosocial behaviour. We should also note that the mechanism of precommitting to donate (rather than actual donating) is an even more specific behaviour. It is certainly the case that most marketing campaigns that strive for donation behaviour do so by requesting such behaviour more directly, without such a precommitment. However, as we have discussed, to have used such a direct measure here would have created the need to explore the endowment effect, which by its very nature is subjective. Furthermore, as we have also reviewed, requesting a precommitment has been shown to be an effective mechanism for engendering a subsequent donation. Nonetheless, further research should check that actual donation does indeed result in a similar manner. Similarly, there is a need to check that this social identity mechanism can result in other sustainability behaviours, as we return to in our final section below.

Overall, the results suggest a novel use of the online consumer environments that are now such a regular part of the consumer experience. It is important to reiterate that the online environment presented here was not an elaborate, well-established brand community, demanding high marketing investment over extended periods, but rather was an extremely basic testing platform, hosted by what can be considered a low-power brand - a brand that had no previous associations or awareness in the minds of consumers. This further adds to the contribution of this research, since it reinforces the potential accessibility to all marketing departments of the social identity mechanisms we have outlined. This research hence points towards a novel route by which to ameliorate the frequently referenced attitude-behaviour gap in sustainable consumption: 
novel both from a theoretical perspective through the use of group social identity effects, and from a practitioner perspective through the use of low-commitment online discussion and engagement platforms to build novel groups.

The results are also encouraging in that the effects on the consumer-brand relationship of engaging in brand-requested sustainability behaviours can be positive. This is perhaps counterintuitive, considering the extant literature on the potential complications that sustainability initiatives can cause within the consumer brand relationship (Aaker et al., 2010). Instead, we have found that provided the group's objectives are appropriately defined to its members, asking consumers within the group to engage in an altruistic behaviour on behalf of a sustainability ambition serves not to weaken that relationship but to strengthen it. In the context of sustainability, it would appear that asking the help of consumers can be beneficial not just for the cause but also for the firm. This points to a new mechanism for overcoming what has been termed the 'sustainability liability' (Luchs et al., 2010), whereby firms attempting to engage their customers in more sustainable endeavours can suffer from the critique that even if consumers recognise the behaviours as inherently desirable, they may not believe that it is the brand's business to ask them to enact them.

Moreover, these results lend support to the argument that social normative requests (Cialdini, Kallgren, \& Reno, 1991) such as 'we should be more sustainable', with descriptive norm support such as commentary within newspapers or magazines, can be effective in influencing behaviour if such requests are made within consumer groups, and even where these groups are novel, provided these groups are convened around these requests that define the purpose and identity of the group. This is because within group environments, consumer members have voluntarily relinquished a degree of autonomy in exchange for joining the group, making the member more susceptible to these social influences (Cialdini \& Nolan, 2005). Our study provides further support for this view, within a highly important practitioner context, and through the use of specific consumer engagement technology. Moreover, the blank canvas nature 
of a novel consumer group means that these requests - presented as a goal of the group - can act effectively as a group identity-defining characteristic.

Finally, this research also supports the argument that primed groups can give rise to positive, constructive behaviours beyond the group, in our case in the form of a precommitment to donate beyond the group. This is a welcome counter-example to much of the thinking around the use of group identity and behaviour change, since groups can often derogate the out-group in the name of securing in-group distinctiveness and status (Tajfel et al., 1971; Tajfel \& Turner, 1979). In our study, we have found support for the argument that this out-group derogation need not be present when group design, behaviours and beneficiaries are considered as part of an online consumer engagement strategy toward more sustainable behaviour. More specifically, where the group and its members can equally effectively garner positive distinctiveness by supporting an out-group (e.g. committing to donate) since such a behaviour is engineered to be identity congruent, then the likelihood to derogate diminishes or disappears. This is a significant implication, we argue, of careful identity and behaviour design by marketers.

\section{Managerial impact}

As businesses face increasing pressure to engage consumers in sustainable practices, the proportion of those consumers who accurately translate apparently strong attitudinal support into concrete behaviours remains small, so exposing businesses attempting sustainability initiatives to risk. However, this study has found support for a route to engage a wider range of consumers, namely the use of group social identity influence to contextualise and strengthen normative requests within accessible and scalable online consumer engagement platforms. We suggest that the relative ease and effectiveness of this approach may be of considerable value to managers who wish to engage consumers in sustainability endeavours. Whilst we acknowledge that food and beverage purchasing may not typically take place in an easily defined social group, many

food and drink brands have worked hard to create online spaces for consumer engagement, some 
of which may be amenable to attention to social identity. For example, PepsiCo's "Crash the SuperBowl" initiative, whereby consumers are asked to crowdsource advertisements for Pepsi or Doritos, creates a temporary community where effects such as those we have described might be expected to be present. In addition, collaborations between brands and retailers may be entirely feasible, using for example retailer websites to create social influences; the relative ease by which the effect was secured in this research suggests the viability and effectiveness of fluid and dynamic marketing partnerships in the name of sustainability.

Independent of product category, our research provides encouragement to managers that such prosocial outcomes may be possible through these social identity influences and via accessible technology-enabled consumer platforms. Furthermore, far from sustainability requests having a detrimental effect on the consumer-brand relationship, they can be positive for it. As these effects were seen even in the context of an experimental brand with no established brand equity, they appear to be within reach of the newest brands and the least well-resourced of marketing teams.

\section{Research Directions}

Our research supports a promising and actionable new route to securing social change towards sustainability. A number of research directions are evident. These include a focus through precisely the same social identity mechanisms on other target consumer behaviours such as giving time to third parties, direct engagement with the company, and purchase of more sustainable products. Research is also needed to understand the moderators and boundary conditions of social identity effects, such as specific product categories, behaviour requests, or brand types. There is also a need to better understand any intertemporal influences on these effects, such as how identity effects decay. Although the extant research shows that securing some sustainable behaviours can result in pro-sustainability attitudes as a result (Cornelissen, Pandelaere, Warlop, \& Dewitte, 2008), further research is needed to understand whether there is 
an 'easy come, easy go' consequence to such priming efforts. There would not be to question the validity of this route to sustainable behaviour necessarily, but rather to better understand what target behaviours may be viable, and at which point the target behaviours should be elicited. In addition, whilst we have justified the use of a precommitment mechanism for donation behaviour in this research (both from an experimental design perspective, and also an ecological validity perspective), we do recognise the limitations of a focus on this mechanism.

With respect to the consumer-brand relationship, we have suggested an identity-based influence that strengthens this relationship as a result of the identity manipulation, namely via positive distinctiveness of the group. Continued investigation of this influence would further enhance the value of social identity routes to sustainable behaviour, potentially revealing yet more novel approaches to securing and strengthening such consumer-brand bonds within what is an increasingly salient context for business and its consumers. 
Acknowledgements

We acknowledge with thanks the assistance of GfK with data collection. 


\section{References}

Aaker, J., Vohs, K. D., \& Mogilner, C. (2010). Nonprofits Are Seen as Warm and For-Profits as Competent: Firm Stereotypes Matter. Journal of Consumer Research, 37(2), 224-237.

Aquino, K., Freeman, D., Reed, A., Felps, W., \& Lim, V. K. G. (2009). Testing a socialcognitive model of moral behavior: the interactive influence of situations and moral identity centrality. Journal of Personality and Social Psychology, 97(1), 123-41.

Ariely, D., \& Wertenbroch, K. (2002). Procrastination, deadlines, and performance: self-control by precommitment. Psychological Science : A Journal of the American Psychological Society / APS, 13(3), 219-224.

Auger, P. (2003). What Will Consumers Pay for Social Product Features? Journal of Business Ethics, 42(3), 281-304.

Auger, P., \& Devinney, T. M. (2007). Do What Consumers Say Matter? The Misalignment of Preferences with Unconstrained Ethical Intentions. Journal of Business Ethics, 76(4), 361-383.

Auger, P., Devinney, T. M., Louviere, J. J., \& Burke, P. F. (2008). Do social product features have value to consumers? International Journal of Research in Marketing, 25(3), 183-191.

Bagozzi, R. P. (1975). Marketing as Exchange. Journal of Marketing, 39(4), 32-39.

Bloom, P., Hussein, P. Y., \& Szykman, L. R. (1997). The benefits of corporate social marketing initiatives. In M. E. Goldberg, M. Fishbein, \& S. E. Middlestadt (Eds.), Social Marketing: Theoretical and Practical Perspectives, 313-335, Mahwah, NJ, US: Lawrence Erlbaum Associates Publishers.

Brewer, M. B., \& Gardner, W. (1996). Who is this "We"? Levels of collective identity and self representations. Journal of Personality and Social Psychology, 71(1), 83-93.

Cialdini, R. B., \& Nolan, J. (2005). Basic Social Influence Is Underestimated. Psychological Inquiry, 16(4), 158-161.

Cialdini, R., Kallgren, C., \& Reno, R. (1991). A Focus Theory of Normative Conduct: A Theoretical Refinement and Reevaluation of the Role of Norms in Human Behaviour. In M. Zanna (Ed.), Advances in Experimental Psychology, 22, 201-234.

Cialdini, R., Reno, R., \& Kallgren, C. (1990). A Focus Theory of Normative Conduct: Recycling the Concept of Norms to Reduce Littering in Public Spaces. Journal of Personality and Social Psychology, 58(2), 1015-1026.

Cornelissen, G., Pandelaere, M., Warlop, L., \& Dewitte, S. (2008). Positive cueing: Promoting sustainable consumer behavior by cueing common environmental behaviors as environmental. International Journal of Research in Marketing, 25(1), 46-55.

Dholakia, U., Bagozzi, R., \& Pearo, L. (2004). A social influence model of consumer participation in network- and small-group-based virtual communities. International Journal of Research in Marketing, 21(3), 241-263. 
Doran, C. J. (2008). The Role of Personal Values in Fair Trade Consumption. Journal of Business Ethics, 84(4), 549-563.

Ellemers, N., Kortekaas, P. \& Ouwerkerk, J. (1999) Self-categorisation, commitment to the group and group self-esteem as related but distinct aspects of social identity. European Journal of Social Psychology, 29(2-3), 371-389.

Hayes, A. (2013) Introduction to Mediation, Moderation and Conditional Process Analysis. A Regression-Based Approach. New York, NY, US: Guilford Press.

Grunert, K. (2011). Sustainability in the Food Sector: A Consumer Behaviour Perspective. International Journal on Food System, 2(3), 207-218.

Guéguen, N. \& Jacob, C. (2013). Behavioral consequences of money: When the automated teller machine reduces helping behavior. Journal of Socio-Economics, 47, 103-104.

Hirsh, J., \& Dolderman, D. (2007). Personality predictors of Consumerism and Environmentalism: A preliminary study. Personality and Individual Differences, 43(6), 15831593.

Hogg, M. A., \& Abrams, D. (1990). Social Motivation, self-esteem and social identity. In D. Abrams \& M. A. Hogg (Eds.), Social Identity Theory: Constructive and Critical Advances, 2847.

Hogg, M. A., \& Turner, J. C. (1985). Interpersonal attraction, social identification and psychological group formation. European Journal of Social Psychology, 15(1), 51-66.

Hogg, M. A., \& Turner, J. C. (1987). Intergroup behaviour, self-stereotyping and the role of social identities. British Journal of Social Psychology, 26, 325-340.

Kahneman, D., Knetsch, J. L., \& Thaler, R. H. (1991). The Endowment Effect, Loss Aversion, and Status Quo Bias. Journal of Economic Perspectives, 5(1), 193-206.

Kilbourne, W., \& Pickett, G. (2008). How materialism affects environmental beliefs, concern, and environmentally responsible behavior. Journal of Business Research, 61(9), 885-893.

Kivetz, R., \& Simonson, I. (2002). Self-Control for the Righteous: Toward a Theory of Precommitment to Indulgence. Journal of Consumer Research, 29(2), 199-217.

Levine, R. M., Evans, D., Prosser, A., \& Reicher, S. (2005). Identity and Emergency Intervention: How Social Group Membership and Inclusiveness of Group Boundaries Shapes Helping Behavior. Personality and Social Psychology Bulletin, 31(4), 443-453.

Lichtenstein, D. R., Drumwright, M. E., \& Braig, B. M. (2004). The Effect of Corporate Social Responsibility on Customer Donations to Corporate-Supported Nonprofits. Journal of Marketing, 68(4), 16-32.

Loewenstein \& Prelec, D., G. (1992). Anomalies in intertemporal choice: Evidence and an interpretation. The Quarterly Journal of Economics, 107(2), 573-597. 
Luchs, M. G., Naylor, R. W., Irwin, J. R., \& Raghunathan, R. (2010). The Sustainability Liability: Potential Negative Effects of Ethicality on Product Preference. Journal of Marketing, 74(5), 18-31.

Macdonald, E. K., \& Sharp, B. M. (2000). Brand Awareness Effects on Consumer Decision Making for a Common, Repeat Purchase Product. Journal of Business Research, 48(1), 5-15.

McAlexander, J. H., Schouten, J. W., \& Koenig, H. F. (2002). Building Brand Community. Journal of Marketing, 66(1), 38-54.

Meyvis, T., Bennett, A., \& Oppenheimer, D. (2010). Precommitment to Charity. In D. Oppenheimer \& C. Olivola (Eds.), The Science of Giving, 35-48, New York, NY, US: Psychology Press.

Miller, N. \& Campbell, D., T. (1959). Recency and primacy in persuasion as a function of timing of speeches and measurements. Journal of Abnormal and Social Psychology, 59, 1-9.

Northrop, E. (2014). Prosperity Without Growth: Economics for a Finite Planet. Eastern Economic Journal, 40(3), 440-442.

Oliver-Solà, J. (2010). Prosperity without Growth? - The transition to a sustainable economy. Journal of Cleaner Production, 18(6), 596-597.

Osterhus, T. L. (1997). Pro-social consumer influence strategies: When and how do they work? Journal of Marketing, 61(4), 16-29.

Papaoikonomou, E., Ryan, G., \& Ginieis, M. (2011). Towards a Holistic Approach of the Attitude Behaviour Gap in Ethical Consumer Behaviours: Empirical Evidence from Spain. International Advances in Economic Research, 17(1), 77-88.

Park, C. W., Macinnis, D. J., Priester, J., \& Eisingerich, A. B. (2010). Brand Attachment and Brand Attitude Strength: Conceptual and Empirical Differentiation of Two Critical Brand Equity Drivers. Journal of Marketing, 74(6), 1-17.

Pepper, M., Jackson, T., \& Uzzell, D. (2009). An examination of the values that motivate socially conscious and frugal consumer behaviours. International Journal of Consumer Studies, $33(2), 126-136$.

Reed, A., Aquino, K., \& Levy, E. (2007). Moral Identity and Judgments of Charitable Behaviors. Journal of Marketing, 71(1), 178-193.

Reed II, A. (2002). Social Identity as a Useful Perspective for Self-Concept-based Consumer Research. Psychology \& Marketing, 19(3), 235-266.

Rutsaert, P., Barnett, J., Gaspar, R., Marcu, A., Pieniak, Z., Seibt, B., Verbeke, W. (2015). Beyond information seeking: Consumers' online deliberation about the risks and benefits of red meat. Food Quality and Preference, 39, 191-201.

Schau, H. J., Muñiz, A. M., \& Arnould, E. J. (2009). How Brand Community Practices Create Value. Journal of Marketing, 73(5), 30-51. 
Schouten, J. W. (2007). Transcendent customer experience and brand community. Journal of the Academy of Marketing Science, 35(3), 357-368.

Shang, J., \& Croson, R. (2006). The Impact of Social Comparisons on Nonprofit Fundraising. In R. M. Isaac \& D. D. Davis (Eds.), Experiments Investigating Fundraising and Charitable Contributors (Research in Experimental Economics), 11, 143-156.

Small, D. A., Loewenstein, G., \& Slovic, P. (2007). Sympathy and callousness: The impact of deliberative thought on donations to identifiable and statistical victims. Organizational Behavior and Human Decision Processes, 102(2), 143-153.

Stern, P. C., Dietz, T., Abel, T., Guagnano, G. A., \& Kalof, L. (1999). A value-belief-norm theory of support for social movements: The case of environmentalism. Human Ecology Review, 6(2), 81-97.

Strahilevitz, M., \& Myers, J. G. (1998). Donations to Charity as Purchase Incentives: How Well They Work May Depend on What You Are Trying to Sell. Journal of Consumer Research, 24(4), 434-446.

Taijfel, H. (1970). Experiments in intergroup discrimination. Scientific American, 223(5), 96102.

Tajfel, H. (1978). The achievement of group differentiation. In H. Tajfel (Ed.), Differentiation between groups: studies in the social psychology of intergroup relations, 77-100, Oxford, England: Academic Press.

Tajfel, H. (1979). Individuals and Groups in Social Psychology. British Journal of Social Psychology, 18(2), 183-190.

Tajfel, H. (1982). Social psychology of intergroup relations. Annual Review of Psychology, 33, 331-39.

Tajfel, H., Flament, C., Billig, M. G., \& Bundy, R. F. (1971). Social categorization and intergroup behaviour. European Journal of Social Psychology, 1, 149-177.

Tajfel, H., \& Turner, J. (1986). The social identity theory of intergroup relations. In W. G. Austin \& S. Worchel (Eds.), The Psychology of Intergroup Relations, 7-24, Oxford, England: Brooks/Cole.

Tajfel, H., \& Turner, J. (1979). An integrative theory of intergroup conflict. In W. G. Austin \& S. Worchel (Eds.), The social psychology of intergroup relations. 33, 33-47.

Turner, J. C. (1985). Social categorization and the self-concept: a social cognitive theory of group behaviour. In E. J. Lawler (Ed.), Advances in Group Processes Theory Research, 2, 77121.

Turner, J. C., \& Oakes, P. J. (1986). The significance of the social identity concept for social psychology with reference to individualism, interactionism and social influence. British Journal of Social Psychology, 25(3), 237-252. 
Turner, J. C., \& Oakes, P. J. (1997). The Socially Structured Mind. In C. McGarty \& S. A. Haslam (Eds.), The message of social psychology, 355-373.

Turner, J. C., Wetherell, M. S., \& Hogg, M. A. (1989). Referent informational influence and group polarization. British Journal of Social Psychology, 28(2), 135-147.

Twenge, J. M., Baumeister, R. F., DeWall, C. N., Ciarocco, N. J., \& Bartels, J. M. (2007). Social exclusion decreases prosocial behavior. Journal of Personality and Social Psychology, 92(1), $56-66$.

Verain, M. C. D., Bartels, J., Dagevos, H., Sijtsema, S. J., Onwezen, M. C., \& Antonides, G. (2012). Segments of sustainable food consumers: a literature review. International Journal of Consumer Studies, 36(2), 123-132.

Vohs, K. D., Mead, N. L., \& Goode, M. R. (2006). The psychological consequences of money. Science, 314(5802), 1154-1156.

White, K., \& Simpson, B. (2013). When Do (and Don't) Normative Appeals Influence Sustainable Consumer Behaviors? Journal of Marketing, 77(2), 78-95.

Winterich, K. P., \& Barone, M. J. (2011). Warm Glow or Cold, Hard Cash? Social Identify Effects on Consumer Choice for Donation Versus Discount Promotions. Journal of Marketing Research, 48(5), 855-868. 


\section{Table 1: Brand-identity congruence manipulation}

\begin{tabular}{|c|c|c|}
\hline CONDITION & HIGH BRAND-IDENTITY CONGRUENCE CONDITION (HC) & LOW BRAND-IDENTITY CONGRUENCE CONDITION (LC) \\
\hline INTRODUCTION & $\begin{array}{l}\text { Having introduced the product we'd now like to introduce and discuss } \\
\text { the two potential launch initiatives for Abundancy. } \\
\text { Both initiatives we want to share with you focus on delivering } \\
\text { Abundancy's commitment to health and well-being - not just for those } \\
\text { who go out and buy Abundancy (our consumers), but for everyone. } \\
\text { Abundancy is committed to a healthy environment and vibrant society. } \\
\text { This is sometimes called a commitment to sustainability, or corporate } \\
\text { social responsibility. }\end{array}$ & $\begin{array}{l}\text { Having introduced the product we'd now like to introduce and discuss the } \\
\text { two potential launch initiatives for Abundancy. } \\
\text { Both initiatives we want to share with you focus on delivering fresh } \\
\text { experiences that are exciting and life-affirming for people with modern, } \\
\text { busy lifestyles. We're keen to show that Abundancy champions great new } \\
\text { experiences for the consumer. }\end{array}$ \\
\hline GROUP GOAL & $\begin{array}{l}\text { Specifically, this is the goal of the research today - to review two } \\
\text { initiatives that we hope will help Abundancy show its commitment to } \\
\text { sustainability. }\end{array}$ & $\begin{array}{l}\text { Specifically this is the goal of the research today - to review two } \\
\text { initiatives that we hope will help Abundancy show its commitment to great } \\
\text { consumer experiences. }\end{array}$ \\
\hline $\begin{array}{l}\text { ENVIRONMENTAL } \\
\text { INITIATIVE }\end{array}$ & $\begin{array}{l}\text { Fewer and fewer of us get to experience, enjoy and respect the natural } \\
\text { world, understanding what it gives us, and how we need to protect the } \\
\text { services it provides us. But as we increasingly ignore nature, and what it } \\
\text { does for us, it looks as if we are actually putting ourselves at risk, in } \\
\text { terms of mental and physical well-being. }\end{array}$ & $\begin{array}{l}\text { The natural world offers incredible opportunities for once-in-a-lifetime } \\
\text { experiences and adventures. Adventures that could never be matches at } \\
\text { home or in man-made environments. We at Abundancy believe the natural } \\
\text { world is the most exciting, exhilarating holiday resort in the world. All it } \\
\text { needs is you to experience it. As holiday experiences go, getting close to } \\
\text { nature is as good as it gets. }\end{array}$ \\
\hline $\begin{array}{l}\text { SOCIETAL } \\
\text { INITATIVE }\end{array}$ & $\begin{array}{l}\text { If there is one thing the Olympics showed us in 2012, it's that sport is } \\
\text { important to us: important for engaging with our loved ones, colleagues } \\
\text { and neighbours and important for the effective functioning of our } \\
\text { communities, and society as a whole. Away from the Olympics, sport is } \\
\text { proven to be a major contributor to physical and mental long term health. } \\
\text { To be clear we are not talking about going to the gym (although training } \\
\text { is important) but the benefits of physical exercise in a team environment. } \\
\text { Exercising with other people who share a similar goal (or who want to } \\
\text { score a goal!) is good for us, both physically and mentally. }\end{array}$ & $\begin{array}{l}\text { If there is one thing the Olympics showed us in 2012, it's that sport is a } \\
\text { great part of life. It provides opportunities to build friendships, learn skills } \\
\text { and share in incredible moments of 'togetherness'. Playing sport can be an } \\
\text { exhilarating experience, can be addictive and can even be a career. Team } \\
\text { sport can also improve your broader career prospects, through creating new } \\
\text { friendships and networks. Whether you play to win, or love the } \\
\text { camaraderie, sport is undeniably one of life's great experiences. }\end{array}$ \\
\hline
\end{tabular}


Figure 1: Example article on environmental initiative - low behaviour-identity congruence (LC) condition

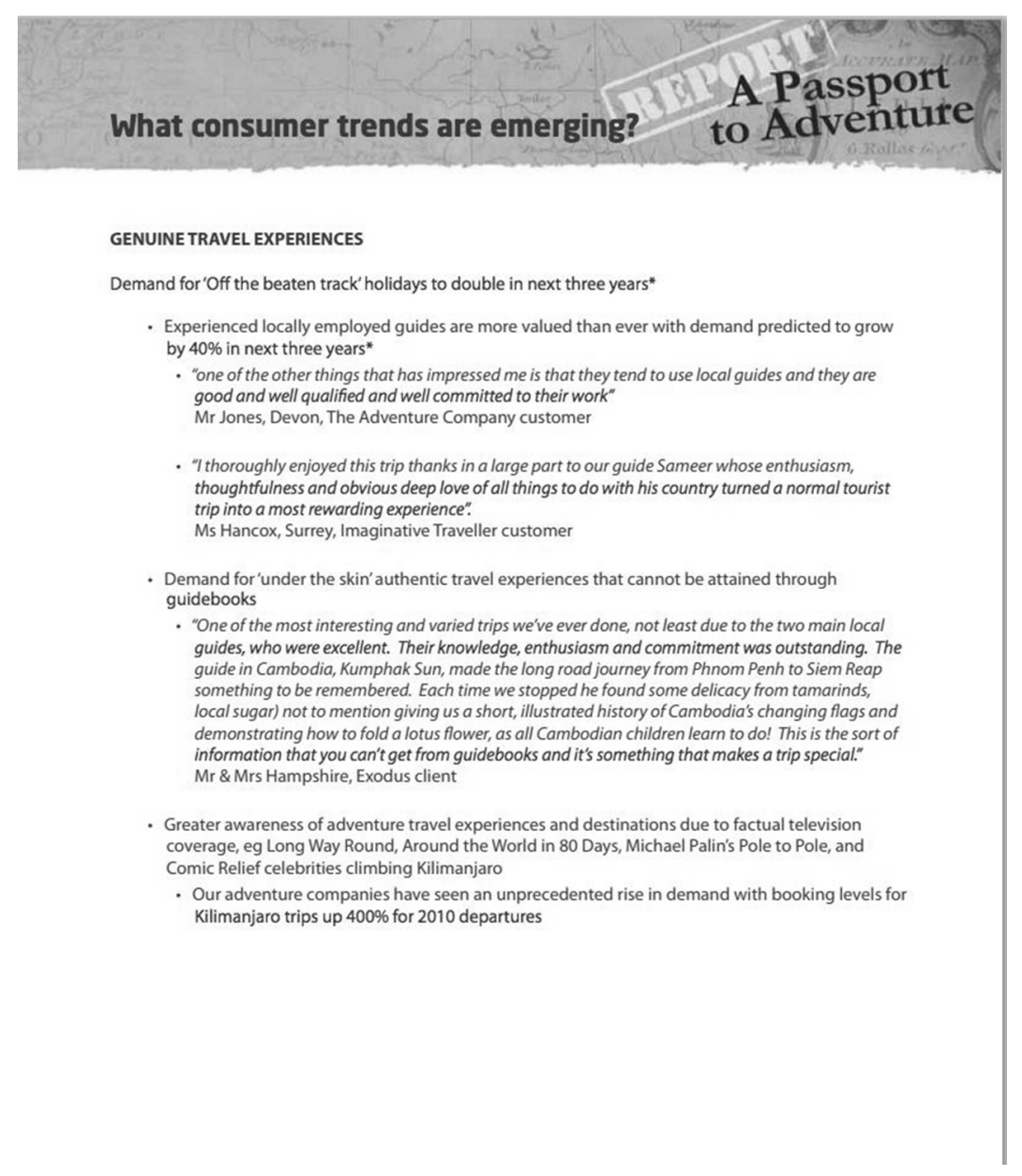


Figure 2: Example article on environmental initiative - high behaviour-identity congruence (HC) condition

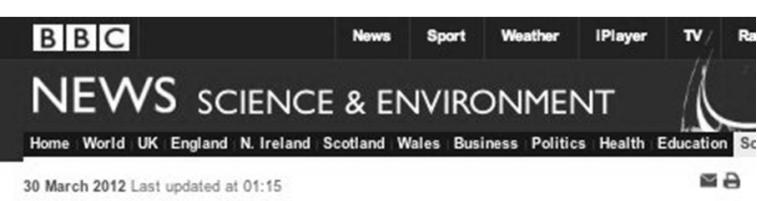

Nature deficit disorder 'damaging Britain's children'

3 A. By Richard Black

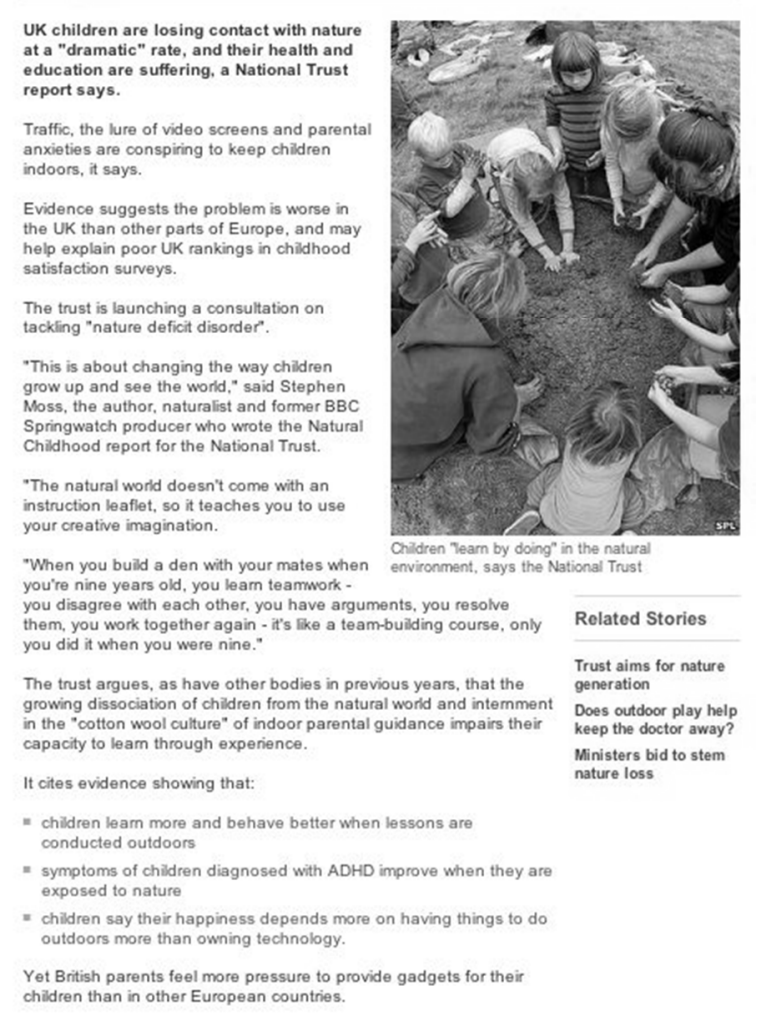




\section{Biographical end note}

Guy Champniss is vice president of consumer behaviour at US consumer technology company Enervee. He was previously Associate Professor in Marketing at Henley Business School. His research focuses on exploring consumer choice and behaviour, including the development of prosocial behaviour. Guy completed his doctorate at Cranfield School of Management. His publications on sustainability marketing include Brand Valued (2011, Wiley), the Admap strategy prize series and a recent article in Harvard Business Review.

Email: guy@enervee.com

Hugh N. Wilson is Professor of Strategic Marketing at Cranfield School of Management and Director of the Customer Management Forum, a syndicate of leading firms exploring best practice in the development of profitable relationships in a multichannel world. Hugh's research and teaching interests focus on marketing planning, multichannel management, CRM and sustainability marketing. He has published in Journal of the Academy of Marketing Science, Journal of Retailing, Harvard Business Review, Industrial Marketing Management and Journal of Business Research amongst others. He is on the editorial board of Journal of the Academy of Marketing Science.

\section{Email: hugh.wilson@cranfield.ac.uk}

Emma K. Macdonald is Associate Professor in Marketing at Cranfield School of Management and Director of the Cranfield Customer Management Forum. She is also Adjunct Senior Research Fellow at the Ehrenberg-Bass Institute at University of South Australia. She researches aspects of customer insight including customer value, customer experience and co-creation. She teaches across a range of postgraduate and executive programmes in the areas of customer experience and communications. She has published in Harvard Business Review, Journal of Retailing, Industrial Marketing Management, Journal of Business Research and Psychology \& Marketing, amongst others.

Email: emma.macdonald@,cranfield.ac.uk

Radu Dimitriu is Lecturer in Strategic Marketing and Director of the MSc in Strategic Marketing and MSc in Retail Management at Cranfield School of Management. He is Visiting Associate Professor at HBV University College in Norway. Radu researches in the areas of consumer behaviour and psychology, branding and brand extensions, consumer pro-social behaviour, and strategic marketing. His teaching is focused on the areas of brand management, consumer behaviour, marketing strategy and planning, and experimental methods of research. He has published in Psychology \& Marketing.

Email: radu.dimitriu@cranfield.ac.uk 


\section{HIGHLIGHTS}

- Shows that social identity can overcome the sustainability attitude-behaviour gap.

- Secures sustainability-aligned behaviours via an online consumer group.

- Prior attitudes are less critical than assumed in securing sustainability behaviours.

- Reveals negative side of group identity - out-group derogation - can be avoided. 
Graphical abstract: Champniss, G., Wilson, H., Macdonald, E.K. and Dimitriu, R., (2016), "No I won't but yes we will”, Technological Forecasting \& Social Change

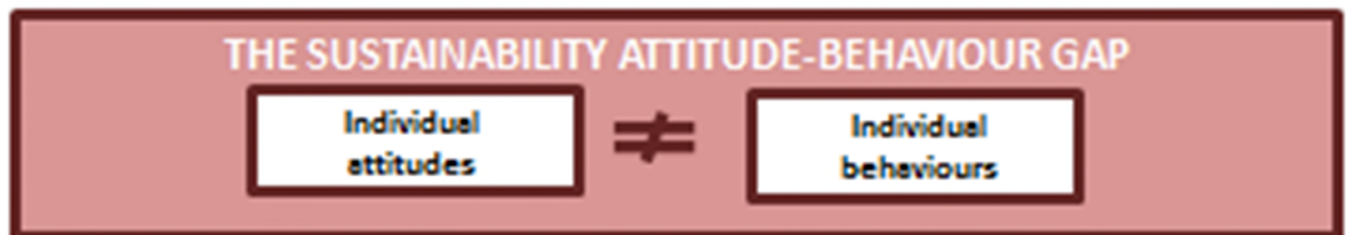

But what if the sustainability request is made of a group?

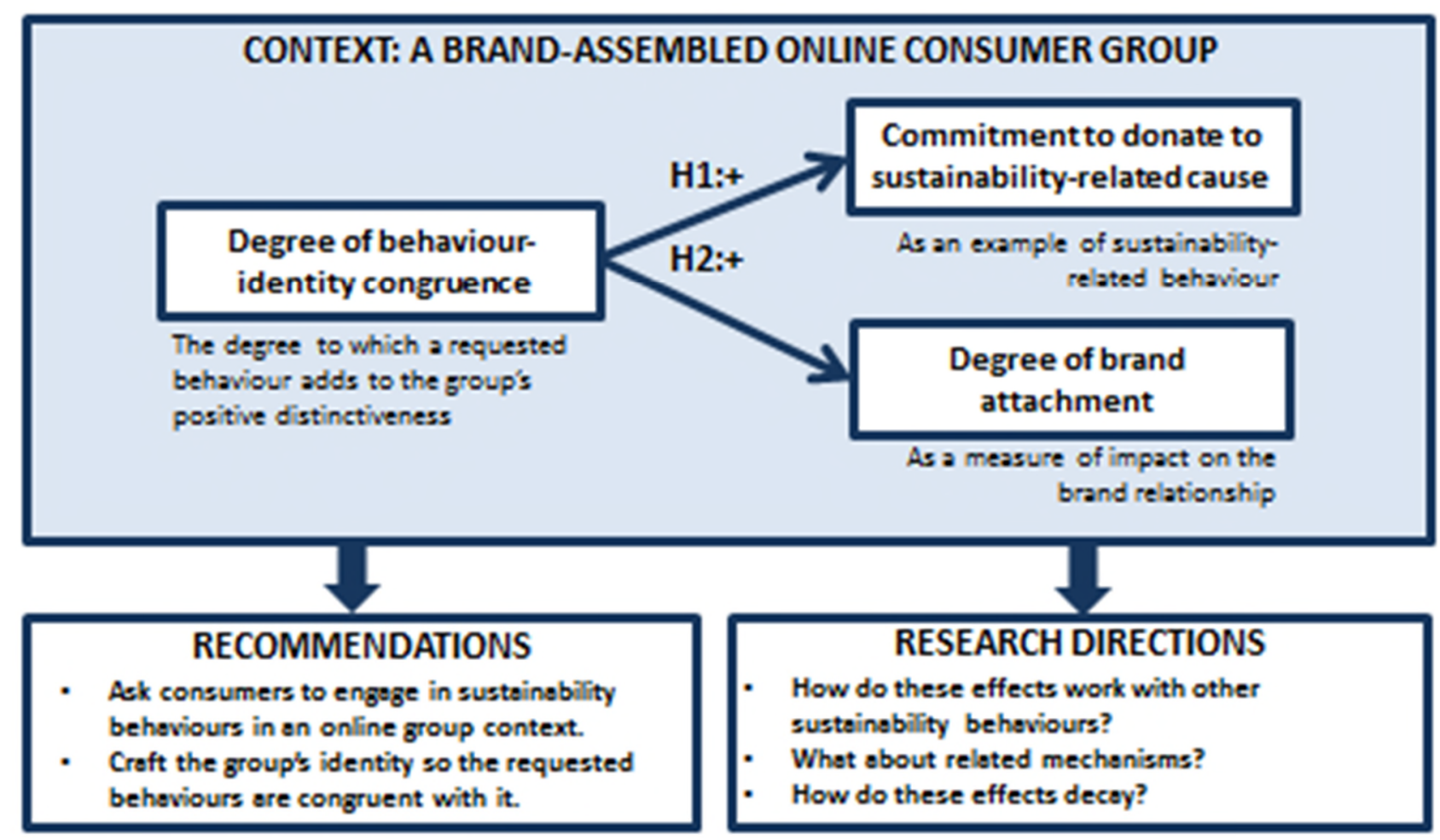

